\title{
UJI TOKSISITAS AKUT EKSTRAK DAUN PSIDIUM GUAVA LINN (DAUN JAMBU BIJI) TERHADAP MENCIT (MUS MUSCULUS)
}

\author{
Amiyatun Naini \\ Bagian Prostodonsia, Fakultas Kedokteran Gigi Universitas Jember
}

Amiyatun Naini. Uji toksisitas akut ekstrak daun psidium guava linn (daun jambu biji) terhadap mencit (mus musculus). Indonesian Journal of Dentistry 2004; 11 (2): 63-65.

\begin{abstract}
The Psidium guava Linn leaf extract as mouthrinse has been suggested to be used against toothache, and also has suggested effect against diarrhea and vomitting, as well as anti spasmodic and rheumatic symptoms, anti inflammation, anti piretic, analgetic, and anti bacterial activity. However, to consider potential side effects, this work aimed to test the acute toxicity of guava leaf extract. For this purpose guava leaf extract was given orally to groups of ten mice each at a doses of $1.25 \mathrm{~g}, 2.5,5,10$ and $21 \mathrm{~g} / \mathrm{kg}$ body weight in a suspension with $\mathrm{CMC} \mathrm{Na} 0,5 \%$. Ten mice were used as control with a dose of $1 \mathrm{ml} \mathrm{CMC} \mathrm{Na} 0,5 \%$. The results suggest no acute toxicity to mice, since even the biggest dose given (show no measurable) value of LD 50. It could be concluded that guava leaf extract shows no acute toxicity to mice at tested concentrations.
\end{abstract}

\section{Pendahuluan}

Penggunaan dan khasiat daun jambu biji telah dikenal oleh masyarakat Indonesia yaitu sebagai obat kumur untuk sakit gigi, sebagai astringen, juga untuk diare dan muntah karena korela, sebagai anti spasmodik; serta pemakaian lokal untuk rematik, anti inflamasi, anti piretik, analgetik dan anti bakteri. ${ }^{1,2,3}$
Daun jambu biji dengan nama latin Psidium guava Linn dan nama simplisia Psidii folium adalah sebagai alternatif obat tradisional. Kandungan kimia dari daun jambu biji terdiri dari tanin, minyak astiri, kuersetin, 3-arabino piranosida, guayaverin, leukosianidin, amritosida, avikularin, asam galat. Tanin bersifat astringen, kandungan minyak asiri dan bahan aktif lain sebagai ramuan anti bakteri. Hasil percobaan farmakologi menunjukkan bahwa daun jambu mempunyai efek antibakteri terhadap Staphylococcus sp. ${ }^{4}$

Setiap bahan atau zat kimia yang merupakan obat atau makanan harus diteliti sifat toksiknya sebelum diperbolehkan penggunaannya secara luas. ${ }^{5} \mathrm{Uji}$ toksisitas sebagai langkah awal untuk melindungi konsumen terhadap kemungkinan bahaya suatu obat. $^{6}$ Manfaat studi 
toksisitas adalah mendapatkan gejala-gejala yang mungkin timbul akibat pemberian obat, mengetahui batas keamanan obat, dan mengetahui derajat kematian hewan coba akibat pemberian obat. $^{\text {? }}$

Toksisitas akut dengan parameter dosis letal median (LD50) toksikan dosis maksimal yang masih dipandang aman, menunjukkan organ sasaran yang mungkin dirusak dan efek toksik spesifiknya, serta memberikan petunjuk tentang dosis yang sebaiknya digunakan dalam pengujian yang lebih lama. LD50 merupakan dosis tunggal suatu zat yang secara statistik diharapkan akan membunuh 50\% hewan $\mathrm{coba}^{7}$, dilakukan sebagai tahap awal penelitian uji toksisitas. Selain itu dari uji toksisitas akut ini pula dapat diketahui kategori toksisitas bahan.

Nilai LD50 berguna untuk mengklasifikasikan zat kimia sesuai dengan efek toksik yang timbul, mengevaluasi efek keracunan yang tidak disengaja, perencanaan penelitian toksisitas subakut dan kronis pada hewan, memberikan informasi mekanisme toksisitas, pengaruh umur, seks, faktor individu, faktor lingkungan, variasi respons antar spesies dan antar strain hewan, memberikan informasi reaktifitas suatu populasi hewan, memberi informasi yang dibutuhkan dalam perencanaan pengujian obat pada manusia dan dalam pengendalian mutu zat kimia, deteksi pencemaran toksik serta perubahan fisik yang mempengaruhi bioavailabilitasnya.?

Berdasarkan uraian di atas maka timbul permasalahan apakah ekstrak daun Psidium guajava Linn (jambu biji) bersifat tidak toksik terhadap mencit (Mus Musculus). Penelitian ini bertujuan untuk menguji toksisitas akut dari ekstrak daun Psidium guava Linn (jambu biji) dan mengetahui harga LD50 ekstrak daun Psidium guajava Linn (jambu biji) yang diaktivasi secara fisik terhadap mencit (Mus Musculus).

\section{Bahan dan Cara Kerja}

Pembuatan ekstrak daun Psidium guajava Linn (jambu biji), daun dikumpulkan dari tanaman yang tumbuh di wilayah Jenggawah Jember pada tanggal 4 Oktober 2003, lalu di identifikasi di laboratorium Botani-Farmasi dan Farmakognosi Fakultas Farmasi Universitas Airlangga. Daun diambil lima lembar dari pucuk lalu dibersihkan. Dikeringkan di dalam ruangan atau terhindar dari cahaya matahari langsung, kemudian digiling sampai halus dan diayak. Serbuk yang diperoleh sesuai dengan kebutuhan, dimasukkan kedalam bejana dituangi pelarut etanol 96\% aduk rata, kemudian dibiarkan pada suhu kamar selama 24 jam sambil diaduk sesering mungkin, lalu disaring dengan penyaring Buchner, ampas di maserasi lagi hingga tiga kali dengan pelarut baru. Maserat yang diperoleh diuapkan/dikeringkan dengan rotavapour sampai diperoleh massa ekstrak kental daun jambu biji.

Digunakan hewan percobaan mencit (Mus Musculus) yang diperoleh dari Fakultas Farmasi Universitas Airlangga, berumur antara 2-3 bulan, berat badan 2030 g. Dibagi menjadi 6 kelompok yang masing-masing terdiri dari 10 ekor mencit jantan dan betina (1:1). Dosis yang diberikan dari dosis terkecil hingga terbesar seperti dibawah ini:

Kelompok 1. Diberi ekstrak dengan dosis $1,25 \mathrm{~g} / \mathrm{kg}$ berat badan.
Kelompok 2. Diberi ekstrak dengan dosis $2,5 \mathrm{~g} / \mathrm{kg}$ berat badan. Ke-lompok 3. Diberi ekstrak dengan dosis $5 \mathrm{~g} / \mathrm{kg}$ berat badan. Kelompok 4. Diberi ekstrak dengan dosis $10 \mathrm{~g} / \mathrm{kg}$ berat badan. Kelompok 5 . Diberi ekstrak dengan dosis 21 $\mathrm{g} / \mathrm{kg}$ berat badan. Kelompok 6 . Kontrol.

Cara pemberian bahan uji melalui jalur yang biasa digunakan pada manusia, umumnya peroral. Setiap hewan coba diberi ekstrak sesuai dengan dosis masing-masing, misalnya pemberian ekstrak dengan dosis $21 \mathrm{~g} / \mathrm{kg}$ berat badan, bila berat badan mencit 20 gr maka berat simplisia atau ekstraknya $0,42 \mathrm{gr}$, begitu juga dosis lainnya. ${ }^{8}$

Pembuatan suspensi ekstrak etanol/fraksi air yaitu ekstrak daun jambu biji ditimbang sesuai dosis, kemudian disuspensikan dalam musilago $\mathrm{CMC} \mathrm{Na} 0,5 \%$ dan diberikan sebanyak $1 \mathrm{ml}$ secara oral. Sebagai kontrol di beri sediaan yang mengandung $\mathrm{CMC} \mathrm{Na}$ $0,5 \%$, dengan cara timbang $0,5 \mathrm{~g}$ $\mathrm{CMC} \mathrm{Na}$, ditaburkan diatas air panas 20-kalinya, dibiarkan mengembang ( \pm 15 menit), gerus sampai homogen. Kemudian dipindahkan ke dalam botol yang telah dikalibrasi dan ditambah aquades sampai $100 \mathrm{ml}$. CMC Na $0,5 \%$ ini diberikan pada kelompok kontrol sebanyak $1 \mathrm{ml}$ secara oral.

Pengamatan tanda-tanda keracunan dilakukan 4 jam setelah pemberian bahan uji, berupa amati pernafasan, tingkah laku, dan pergerakan mencit. Selanjutnya mencit diamati dalam waktu 24 jam selama 7 hari sampai 14 hari setelah pemberian bahan uji. Amati gejala-gejala yang terjadi pada hewan coba yaitu jumlah hewan yang mati, perubahan perilaku, perubahan kondisi tubuh dan perubahan berat badan. Datadata yang diperoleh dalam penelitian ini diolah dengan uji Chi-Square. 
Tabel 1. Pengelompokan sampel dan reaksisemuatiar Pengan demikian dapat disimpulkan bahwa bahwa ekstrak

\begin{tabular}{cll}
\hline $\begin{array}{c}\text { Kelom } \\
\text { pok }\end{array}$ & \multicolumn{1}{c}{ Dosis } & Reaksi kematian \\
\hline 1 & Diberi ekstrak dengan dosis $1,25 \mathrm{~g} / \mathrm{kg}$ berat badan & Tidak ada (0) \\
2 & Diberi ekstrak dengan dosis $2,5 \mathrm{~g} / \mathrm{kg}$ berat badan & Tidak ada (0) \\
3 & Diberi ekstrak dengan dosis $5 \mathrm{~g} / \mathrm{kg}$ berat badan & Tidak ada (0) \\
4 & Diberi ekstrak dengan dosis $10 \mathrm{~g} / \mathrm{kg}$ berat badan & Tidak ada (0) \\
5 & Diberi ekstrak dengan dosis $21 \mathrm{~g} / \mathrm{kg}$ berat badan & Tidak ada (0) \\
6 & Kontrol & Tidak ada (0) \\
\hline
\end{tabular}

\section{Hasil Penelitian}

Hasil uji toksisitas akut pada mencit setelah di beri perlakuan.

Dari data hasil uji toksisitas akut pada mencit diketahui bahwa dosis ekstrak terkecil sampai terbesar yaitu $1,25 \mathrm{~g} / \mathrm{kg}$ berat badan, 2,5 $\mathrm{g} / \mathrm{kg}$ berat badan, 5 $\mathrm{g} / \mathrm{kg}$ berat badan, $10 \mathrm{~g} / \mathrm{kg}$ berat badan dan $21 \mathrm{~g} / \mathrm{kg}$ berat badan pada mencit tidak ada perubahan perilaku, tidak ada perubahan kondisi tubuh, tidak ada perubahan berat badan, dan tidak ada reaksi kematian. Demikian pula pada kelompok kontrol. Pada dosis yang terbesar relatif tidak berbahaya) yaitu 0,42 gr ekstrak daun jambu biji / 20 gr BB mencit belum memberikan respons berupa kematian pada mencit. Dengan uji chi square tidak dapat diukur secara statistik karena dalam pengamatan, konstan yaitu jumlah mencit dalam kelompok perlakuan 50 hidup semua dan kelompok kontrol 10 hidup semua. Dengan demikian dapat disimpulkan bahwa ekstrak daun jambu biji bersifat tidak toksik

\section{Pembahasan}

Pada penelitian ini hewan coba yang digunakan adalah mencit (Mus Musculus) tikus rumah dari Amerika Utara dan Eropa. Mencit termasuk anggota dari ordo Rodensia, famili Muridae, dan sub famili Murinae, yang paling banyak digunakan dalam riset medis modern. Keuntungan dari hewan coba mencit adalah ukuran tubuh kecil, harga lebih murah, mudah di dapat, penanganannya mudah dan terdapat banyak data toksikologi jenis hewan ini. ${ }^{6}$ Dari data hasil uji toksisitas akut pada mencit diketahui bahwa pada dosis terbesar yang diberikan (relatif tidak berbahaya) ternyata belum memberikan respons berupa kematian. Berarti semua toksisitas akut yang berbahaya dapat disingkirkan dan LD50 tidak perlu ditentukan.

\section{Daftar Pustaka}

1. Anonim. The Wealth of India, Vol VIII, Council of Scientific and Industrial Research, New Delhi, 1984; 285-93.

2. Bambang. Tampil percaya diri dengan ramuan tradisional, edisi II, Jakarta: Penerbit Swadaya 2000; 70-1.

3. Sen T, Hussam $\mathrm{SH}$, Nusralla Chauduri, NAK. Phytotherapy Res 1995; 9: 118-19.

4. Anonim. Penelitian Tanaman Obat di beberapa Perguruan Tinggi di Indonesia, Pusat Penelitian dan Pengembangan Farmasi, Departemen Kesehatan RI, 1994: 203-5.

5. Gani-Sulistia. Farmakologi dan Terapan, edisi 4, Bagian Farmakologi Universitas Indonesia Jakarta 1995: 763-7.

6. Klaasen, Curtis D. Cassarett and Doull's toxicology: The Basic Science of Poisons, edisi 5, London: Mc Graw-Hill, 1995: 14.

7. Lu C. Toksikologi Dasar: Asas organ sasaran dan penelitian resiko, edisi 2, Jakarta UI Press 1995: 74,86-97.

8. Derelanko MJ, Hollinger MA. CRC Handbook of Toxicology, edisi V, New York: CRC Press 1995: 657. 